\title{
INTER-RELATIONSHIPS BETWEEN YIELD AND YIELD ATTRIBUTES OF POTATO GROWN UNDER SUPRA-OPTIMAL AMBIENT TEMPERATURES
}

\section{O. AMADI, E. E. ENE-OBONG, J. C. OKONKWO AND P. I. OKOCHA}

(Received 27, August 2007; Revision Accepted 29, August 2008)

\begin{abstract}
Forty eight potato genotypes were evaluated in Saminaka (Lat. $10^{\circ} 27^{\prime} \mathrm{N}$ and Long $4^{0} \mathrm{E}$, Mean Min. Temp $25^{\circ} \mathrm{C}$, Mean Max Temp $31.5^{\circ} \mathrm{C}$ ) during the rainy season of 1999 and 2000 to determine the inter-relationship between yield and some important agronomic traits in the potato grown under high ambient temperatures. The genotypes were laid out in a randomized complete block design with three replications. The genotypes exhibited highly significant variability $(P<0.01)$ for all traits assessed. Tuber yield was positively associated with number of stems/plant $(r=0.246$, $P<0.05)$; plant height $(r=0.206, P<0.05)$; and number of leaves/plant $(r=0.237, P<0.05)$. Both the correlation and regression of yield on days to tuber initiation and days to maturity were negative and significant. This suggests that earliness in tuber initiation and maturity led to increased yield under supra optimal temperature probably due to reduced period of exposure to heat stress. Number of tubers per plant $\left(R^{2}=0.383\right)$ and average tuber weight per plant $\left(R^{2}=0.125\right)$ had the highest coefficients of determination of yield and by far the highest direct effects on yield $(87.5 \%$ and $66.9 \%$ respectively) when compared to other attributes suggesting that they were the major contributors to yield under supra-optimal temperature conditions and may be relied upon in selecting for improved yield under such conditions.
\end{abstract}

KEYWORDS: Potato, genotypes, supra-optimal temperature, tuber yield, selection

\section{INTRODUCTION}

The Potato Solanum tuberosum $L$ is generally best adapted to cool temperate zones (Hawkes, 1978). The optimum temperature for tuber formation and growth for most potato cultivars is about $15-20^{\circ} \mathrm{C}$ (Borah and Milthorpe, 1962). In tropical lowland parts of Africa, potatoes are exposed to day and night temperatures far above the optimum. Almost all potato cultivars bred in northern latitudes respond to such conditions with delayed emergence (Allen, et al. 1992), excessive haulm growth at the expense of the tubers (Ewing, 1981), increased rate of respiration (Sale, 1974), reduced dry matter accumulation (Bushnell, 1925), delayed tuber initiation (Menzel, 1980, Nowak and Coleborne, 1989) and maturity (Amadi, 2005) and a significant loss of tuber yield and quality (Levy, 1983, 1984). The adverse effect of high temperature on tuber yield and quality of potato is a major constraint for potato production in hot regions, and local breeding for heat tolerant cultivar is necessary to improve potato crops in hot environment (Levy, 1984). Analysis of the interrelationship among important agronomic characters in the available germplasm is vital to the attainment of the objective of breeding for heat tolerance. The objective of this work is to furnish information on the interrelationship between yield and yield components with a view to identifying characters of utmost importance which can be used as selection indices for tuber yield improvement in the potato germplasm exposed to heat stress prevalent in locations with supra optimal temperatures.

\section{MATERIALS AND METHODS}

Field experiments were carried out in Saminaka during the rainy season of 1999 and 2000. Saminaka is situated at Lat. $10^{\circ} 27^{\prime} \mathrm{N}$ and Long $4^{\circ} \mathrm{E}$ in Kaduna State of Nigeria. Ambient temperature and rainfall data of Saminaka for the relevant months covering the duration of the experiment in 1999 and 2000 are shown in Fig 1. Forty-eight potato genotypes were evaluated. These genotypes were laid out in a randomized complete block design with 3 replications. Net plot size was $6 \mathrm{~m}^{2}$ and gross plot size was $12 \mathrm{~m}^{2}$. The seed tubers were planted at the rate of 1 tuber per stand, inter-row spacing of $1 \mathrm{~m}$ and an intra-row spacing of $30 \mathrm{~cm}$ giving a plant density of 33,333 plants per hectare. Weeding was carried out manually at 4 and 8 weeks after planting (WAP). Fertilizer was applied by band placement at the rate of $100 \mathrm{~kg} \mathrm{~N}, 100 \mathrm{~kg} \mathrm{P}_{2} \mathrm{O}_{5}$ and $40 \mathrm{~kg} \mathrm{~K}_{2} \mathrm{O}$ per hectare two weeks after planting. No fungicides were applied. The plants were harvested when the leaves began to senesce. Desiree, a cultivar well known for some degree of heat tolerance (Midmore, 1984) was used as a check.

Data were collected on the following attributes: seedling emergence at 4 WAP, number of stems per plant, plant height $(\mathrm{cm})$, number of leaves per plant,

C. O. Amadi, National Root Crops Research Institute Umudike, Potato Programme Kuru, PMB 04 Vom, Jos, Nigeria.

E. E. Ene-Obong, Department of Agronomy CCSS Michael Okpara University of Agriculture Umudike, Nigeria.

J. C. Okonkwo, National Root Crops Reasearch Institue Umudike, PMB 7008 Umuahia, Nigeria.

P. I. Okocha,. Department of Agronomy CCSS Michael Okpara University of Agriculture Umudike, Nigeria. 
days to tuber initiation, days to maturity, severity of early blight, number of wilted stands, number of tubers per plant, average tuber weight/plant, and tuber yield per plant. These attributes were measured as follows

Seedling emergence:- Emergence per plot was recorded at 4 weeks after planting by counting the number of stands whose shoots have broken though the soil surface.

Number of stems per plant:- Only the main stems i.e. those originating from the mother tubers were counted. The record was taken at full flowering.

Plant height $(\mathrm{cm})$ :- Plant height was obtained by measuring from the base of the plant to the apical bud. The measurement was taken at the 8th week after planting.

Number of leaves per plant:- The compound leaves from the base to the tip of the plants counted at 8 weeks after planting.

Days to tuber initiation:- This was counted from planting to the time when the first tuber is initiated by any plant in the plot. A plant was considered to have formed tubers when the swelling at the end of the stolon was twice by visual estimates the diameter of its stolon. To observe this the soil around the base of the plants were carefully removed to expose the stolon and replaced after observation.
Days to maturity:- This was obtained by counting the number of days from planting to the time when less than $50 \%$ of the canopy remain green.

Early blight severity:- Early blight severity was recorded at 10 weeks after planting based on a scale developed by Martin and Thurston, (1987). The scale ranges from 1 to 9 with a mid point of 4 .

$\begin{array}{lll}1 & = & \text { No blight spots seen on the foliage } \\ 4 & = & 25-50 \% \text { of the foliage infected by blight } \\ 9 & = & \text { foliage completely covered/killed by } \\ \text { blight. }\end{array}$

Incidence of bacterial wilt:- The number of stands with bacterial wilt symptoms per plot.

Number of tubers per plant:- This was obtained by counting the whole tubers produced by a plant

Average tuber weight per plant:- This was obtained by dividing the total weight of the tubers produced by each sampled plant by the number of tubers

Tuber yield:- The total weight of tubers/plant

Statistical analysis was performed on plot means for all attributes. Analysis of variance, regression analysis, multiple correlation and regression were carried out using the STATVIEW for windows software. Simple correlation analysis was carried out according to the method outlined by Gomez and Gomez, (1984) where $\mathrm{r}=\sum \mathrm{xy} / \sqrt{ }\left(\sum \mathrm{x} 2\right)\left(\sum \mathrm{y} 2\right)$

Path-coefficient analysis was carried out according to the method outlined by Dewey and Lu (1959).

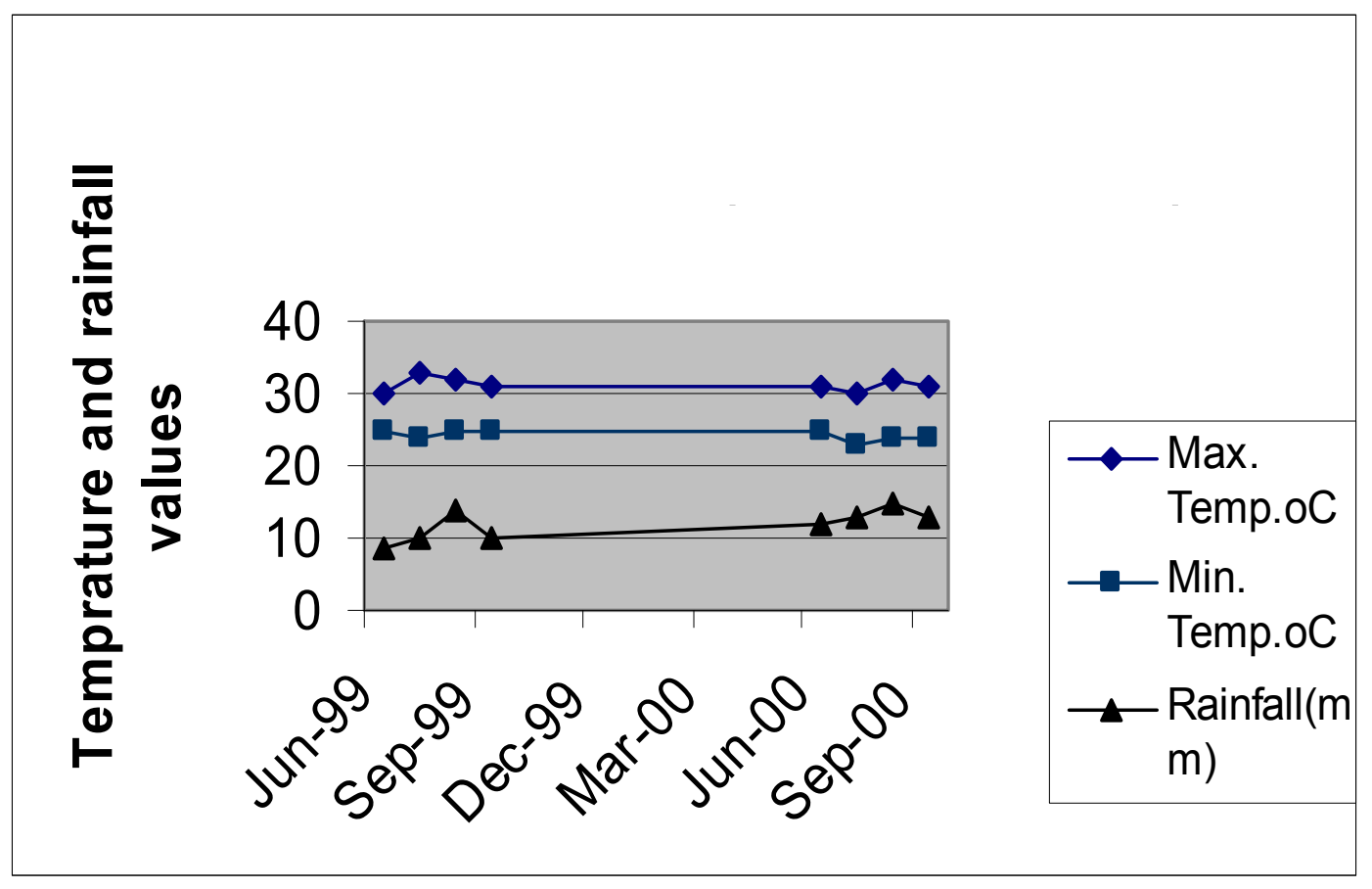

Fig. 1: Temperature and rainfall data of Saminaka (1999 and 2000)

\section{RESULTS AND DISCUSSION}

\section{Analysis of variance}

The analysis of variance (ANOVA) is summarized in Table 1. The mean values of the various attributes are shown in Table 2. There were significant differences between the potato genotypes in all the attributes assessed. Variations among the potato genotypes for different traits have been reported by various authors (Sidhu and Pandita, 1979; and Birhman and Kang, 1993). Highly significant variability in plant attributes within a population suggests the existence of sufficient variability upon which selection for improvement in these attributes can be based. 
Table1: Values of sum of squares (SS), mean squares (MS) and variance ratios (VR) from ANOVA for plant attributes in Saminaka (1999)

\begin{tabular}{|c|c|c|c|c|}
\hline Attributes & $\begin{array}{l}\text { Source of } \\
\text { variation }\end{array}$ & $\mathrm{SS}$ & $\mathrm{MS}$ & VR \\
\hline \multirow[t]{2}{*}{ Plant Emergence } & genotype & 127.97 & 2.72 & $2.92 * * *$ \\
\hline & error & 87.57 & 0.93 & \\
\hline \multirow{2}{*}{$\begin{array}{l}\text { Number of } \\
\text { stems/plant }\end{array}$} & genotype & 26.28 & 0.56 & $5.18 * * *$ \\
\hline & error & 10.14 & 0.11 & \\
\hline \multirow[t]{2}{*}{ Plant height } & genotype & 6729.07 & 143.17 & $18.49 * * *$ \\
\hline & error & 727.97 & 7.74 & \\
\hline \multirow{2}{*}{$\begin{array}{l}\text { Number of } \\
\text { leaves/plant }\end{array}$} & genotype & 55193.47 & 1174.33 & $55.60 * * *$ \\
\hline & error & 1985.54 & 21.12 & \\
\hline \multirow{2}{*}{$\begin{array}{l}\text { Days to tuber } \\
\text { initiation }\end{array}$} & genotype & 2762.89 & 58.79 & $2841.83 * * *$ \\
\hline & error & 1.94 & 0.02 & \\
\hline \multirow[t]{2}{*}{ Days to maturity } & genotype & 2706.64 & 57.59 & $233.81 * * *$ \\
\hline & error & 23.15 & 0.25 & \\
\hline \multirow{2}{*}{$\begin{array}{l}\text { Early blight } \\
\text { severity }\end{array}$} & genotype & 51.97 & 1.11 & $21.20 * * *$ \\
\hline & error & 4.90 & 0.05 & \\
\hline \multirow{2}{*}{$\begin{array}{l}\text { Number of wilted } \\
\text { stands }\end{array}$} & genotype & 80.33 & 1.71 & $3.64 * * *$ \\
\hline & error & 44.15 & 0.47 & \\
\hline \multirow{2}{*}{$\begin{array}{l}\text { Number of } \\
\text { tubers/plant }\end{array}$} & genotype & 154.73 & 3.29 & $3.49 * * *$ \\
\hline & error & 88.81 & 0.95 & \\
\hline \multirow{2}{*}{$\begin{array}{l}\text { Average tuber } \\
\text { weight }\end{array}$} & genotype & 9129.50 & 194.25 & $3.37 * * *$ \\
\hline & error & 5414.38 & 57.60 & \\
\hline \multirow{2}{*}{$\begin{array}{l}\text { Tuber Yield/plant } \\
\text { (g) }\end{array}$} & genotype & 191922.57 & 4083.46 & $3.14 * * *$ \\
\hline & error & 122457.76 & 1302.74 & \\
\hline
\end{tabular}


Table 2: Mean for various potato plant attributes studied at Saminaka the year 2000

\begin{tabular}{|c|c|c|c|c|c|c|c|c|c|c|c|}
\hline Genotype & $\begin{array}{l}\text { \%Emergence } \\
\text { (4WAP) }\end{array}$ & $\begin{array}{l}\text { Number } \\
\text { of } \\
\text { Stems/ } \\
\text { plant }\end{array}$ & $\begin{array}{l}\text { Plant } \\
\text { height } \\
(\mathrm{cm})\end{array}$ & $\begin{array}{l}\text { Number of } \\
\text { leaves } \\
\text { /plant }\end{array}$ & $\begin{array}{l}\text { Days to } \\
\text { Tuber } \\
\text { Initiation }\end{array}$ & $\begin{array}{l}\text { Days to } \\
\text { maturity }\end{array}$ & $\begin{array}{l}\text { Early } \\
\text { blight } \\
\text { severity }\end{array}$ & $\begin{array}{l}\text { Number of } \\
\text { wilted } \\
\text { stands } / \mathrm{m}^{2}\end{array}$ & $\begin{array}{l}\text { Number } \\
\text { Tuber } \\
\text { /plant }\end{array}$ & $\begin{array}{l}\text { Average } \\
\text { tuber } \\
\text { weight/ } \\
\text { plant }\end{array}$ & $\begin{array}{l}\text { Tuber } \\
\text { Yield } \\
(\mathrm{t} / \mathrm{ha})\end{array}$ \\
\hline 392286.14 & 80 & 1.43 & 46.1 & 62.1 & 49.0 & 97.0 & 4.0 & 1.00 & 4.8 & 34.0 & 5.44 \\
\hline RC7716-17 & 90 & 2.03 & 46.0 & 41.3 & 48.0 & 81.0 & 5.0 & 0.89 & 3.5 & 38.4 & 6.28 \\
\hline Nicola & 80 & 1.27 & 39.3 & 40.1 & 50.0 & 92.0 & 5.0 & 0.33 & 2.3 & 34.5 & 2.65 \\
\hline Kondor & 73 & 1.60 & 46.3 & 38.1 & 54.0 & 94.0 & 3.0 & 1.22 & 4.8 & 43.0 & 6.31 \\
\hline 391538.3 & 80 & 1.30 & 42.2 & 52.4 & 50.0 & 89.0 & 3.0 & 1.22 & 4.7 & 32.0 & 4.76 \\
\hline RC777-8 & 80 & 2.40 & 44.1 & 53.6 & 59.0 & 88.0 & 3.7 & 1.11 & 3.3 & 39.2 & 4.28 \\
\hline Baraka & 83 & 1.80 & 41.6 & 43.7 & 46.0 & 92.0 & 3.0 & 0.89 & 6.0 & 32.4 & 6.28 \\
\hline 392011.041 & 67 & 1.20 & 45.5 & 35.8 & 57.3 & 91.0 & 4.0 & 1.00 & 2.8 & 40.8 & 3.93 \\
\hline RC7716-3 & 87 & 1.30 & 54.3 & 64.1 & 51.0 & 83.3 & 3.0 & 1.00 & 2.6 & 36.8 & 3.15 \\
\hline 392277.41 & 90 & 2.07 & 50.2 & 51.5 & 45.0 & 85.0 & 4.0 & 0.89 & 7.1 & 33.1 & 7.00 \\
\hline 392225.047 & 67 & 2.50 & 52.3 & 47.7 & 49.0 & 87.0 & 3.0 & 0.89 & 2.9 & 56.1 & 4.65 \\
\hline 392287.048 & 83 & 1.53 & 53.3 & 45.3 & 58.7 & 90.0 & 3.0 & 1.11 & 3.2 & 37.0 & 3.89 \\
\hline ML98.12 & 87 & 1.53 & 45.2 & 43.7 & 49.0 & 92.0 & 4.0 & 1.11 & 3.1 & 40.5 & 3.89 \\
\hline B9449-17 & 83 & 1.70 & 36.5 & 46.0 & 54.0 & 87.7 & 3.3 & 0.89 & 5.2 & 32.8 & 5.26 \\
\hline Alpha & 63 & 1.60 & 43.0 & 52.7 & 60.0 & 98.0 & 3.0 & 1.11 & 2.6 & 37.2 & 3.22 \\
\hline 392243.048 & 63 & 1.53 & 44.8 & 41.6 & 49.0 & 87.0 & 3.0 & 1.33 & 3.2 & 35.0 & 3.54 \\
\hline BR63-18 & 80 & 2.40 & 45.9 & 33.1 & 45.0 & 86.0 & 4.0 & 1.78 & 3.2 & 47.5 & 5.15 \\
\hline WC732-1 & 73 & 2.63 & 42.3 & 87.6 & 50.0 & 90.0 & 4.0 & 1.67 & 4.0 & 39.8 & 5.65 \\
\hline Greta & 63 & 2.20 & 43.8 & 44.3 & 58.0 & 94.9 & 4.0 & 0.89 & 3.1 & 44.0 & 3.85 \\
\hline LadyChriste & 63 & 1.87 & 45.9 & 42.9 & 55.0 & 92.0 & 4.0 & 1.11 & 3.2 & 37.5 & 4.02 \\
\hline 392282.061 & 73 & 1.60 & 40.1 & 54.1 & 49.0 & 92.0 & 4.3 & 1.00 & 4.4 & 33.2 & 3.70 \\
\hline 392207.042 & 90 & 1.83 & 36.2 & 44.2 & 53.0 & 88.0 & 4.0 & 1.00 & 2.1 & 41.7 & 2.78 \\
\hline 392269.027 & 87 & 1.33 & 49.9 & 56.8 & 54.0 & 98.0 & 3.0 & 1.00 & 2.6 & 40.8 & 3.69 \\
\hline ML98.14 & 67 & 1.90 & 47.7 & 60.6 & 44.0 & 86.0 & 4.0 & 0.89 & 3.5 & 42.9 & 4.72 \\
\hline Redone & 90 & 2.27 & 53.9 & 44.5 & 50.0 & 87.0 & 4.0 & 1.00 & 3.9 & 36.8 & 4.57 \\
\hline ML98.015 & 90 & 2.43 & 53.6 & 62.4 & 48.0 & 99.0 & 4.0 & 1.00 & 3.2 & 43.3 & 4.59 \\
\hline 392288.044 & 60 & 1.63 & 55.2 & 43.3 & 50.0 & 91.3 & 3.0 & 1.56 & 2.7 & 43.9 & 3.85 \\
\hline VC785-2 & 80 & 1.90 & 55.6 & 63.8 & 51.0 & 81.0 & 3.3 & 1.00 & 3.6 & 44.0 & 4.85 \\
\hline Roslin Ruaka & 87 & 1.30 & 48.8 & 54.3 & 55.0 & 92.0 & 3.0 & 1.44 & 3.0 & 44.3 & 4.28 \\
\hline 384300.8 & 77 & 2.27 & 30.6 & 35.1 & 58.0 & 96.0 & 3.0 & 1.00 & 3.3 & 34.3 & 3.59 \\
\hline 392010.12 & 7.3 & 2.23 & 42.1 & 53.1 & 52.0 & 91.0 & 4.0 & 1.33 & 4.1 & 32.9 & 4.56 \\
\hline
\end{tabular}




\begin{tabular}{|c|c|c|c|c|c|c|c|c|c|c|c|}
\hline 377865.35 & 73 & 1.73 & 47.8 & 71.1 & 52.0 & 89.0 & 3.0 & 1.00 & 5.1 & 42.5 & 6.50 \\
\hline 392280.1 & 80 & 2.00 & 42.3 & 56.8 & 47.0 & 86.3 & 3.0 & 0.89 & 3.0 & 66.7 & 6.19 \\
\hline RC7716-3 & 70 & 2.10 & 60.8 & 68.3 & 51.0 & 84.7 & 3.0 & 1.22 & 3.5 & 72.7 & 7.52 \\
\hline 392282.010 & 60 & 1.37 & 54.5 & 62.9 & 50.0 & 93.0 & 3.0 & 1.11 & 3.7 & 44.7 & 5.24 \\
\hline Rosamunda & 90 & 2.23 & 35.9 & 30.0 & 44.0 & 85.0 & 4.0 & 1.44 & 2.9 & 32.6 & 2.76 \\
\hline 392278.4 & 73 & 1.30 & 52.4 & 46.8 & 58.7 & 90.0 & 3.0 & 1.00 & 4.6 & 34.0 & 4.52 \\
\hline LL98.01 & 70 & 1.57 & 47.0 & 54.3 & 49.0 & 90.0 & 3.0 & 0.89 & 3.3 & 41.6 & 4.57 \\
\hline 392228.045 & 57 & 1.93 & 34.1 & 49.6 & 44.0 & 82.7 & 5.0 & 1.44 & 4.6 & 40.5 & 5.48 \\
\hline 392281.040 & 77 & 2.07 & 44.9 & 57.1 & 46.0 & 92 & 4.0 & 1.00 & 5.2 & 42.2 & 6.37 \\
\hline 392260.30 & 77 & 2.07 & 46.5 & 62.4 & 50.0 & 92 & 3.7 & 1.22 & 3.3 & 43.5 & 4.28 \\
\hline 387300.8 & 90 & 1.30 & 51.3 & 148.7 & 50.0 & 91.7 & 3.0 & 1.00 & 3.9 & 41.2 & 5.05 \\
\hline Desiree & 90 & 3.00 & 62.4 & 110.5 & 54.0 & 94.0 & 3.0 & 1.56 & 5.3 & 43.3 & 7.30 \\
\hline Famosa & 77 & 1.83 & 52.1 & 65.4 & 53.0 & 90.0 & 3.0 & 1.11 & 3.7 & 42.1 & 4.94 \\
\hline 392280.029 & 77 & 1.57 & 46.7 & 45.2 & 50.0 & 90.0 & 3.0 & 1.00 & 4.1 & 34.5 & 4.22 \\
\hline 392246.017 & 67 & 1.43 & 36.1 & 44.6 & 44.0 & 89.0 & 4.0 & 1.22 & 4.0 & 52.0 & 6.26 \\
\hline Accent & 73 & 2.60 & 40.8 & 44.8 & 45.0 & 90.0 & 4.0 & 1.33 & 6.0 & 34.3 & 6.61 \\
\hline Bertita & 77 & 1.87 & 56.6 & 39.3 & 46.0 & 80.0 & 4.0 & 1.33 & 4.3 & 46.5 & 5.91 \\
\hline $\mathrm{CV} \%$ & 12.6 & 17.8 & 5.98 & 8.49 & 0.28 & 0.55 & 6.40 & 20.52 & 25.56 & 18.54 & 24.88 \\
\hline SED & 7.881 & 0.268 & 2.272 & 3.753 & 0.117 & 0.405 & 0.187 & 0.187 & 0.794 & 6.197 & 0.982 \\
\hline
\end{tabular}




\section{Inter relationships between yield and yield components}

The simple correlation coefficients between attributes studied and simple regression coefficients for the regression between yield and yield components are shown in Tables 3 and 4 respectively. Tuber yield was positively associated with stem number $(r=0.246$, $P<0.05)$; plant height $(r=0.206, P<0.05)$; number of leaves $(r=0.237, P<0.001)$ while plant height was positively correlated with number of leaves. The regression of yield on plant height, stem number and number of leaves per plant reflected the correlation. Lopez et al (1987) detected a significant positive correlation between plant height and tuber yield. Taller genotypes had more leaves, which enabled them to produce more photosynthate for storage in the tubers. This suggests that optimal shoot development is necessary for improved yields under supra optimal ambient temperature conditions. However since high temperature favour shoot growth by decreasing the partitioning of assimilates to tubers (Ewing, 1981) care must be taken not to exceed the optimum.

Both the correlation and regression of yield on days to tuber initiation and days to maturity were negative and significant. This suggests that earliness in tuber initiation and maturity led to increased yield under supra optimal temperature probably due to reduced period of exposure to heat stress.

Number of tubers per plant correlated positively with tuber yield in this study. This result agrees with the report by Lopez et al, (1987). However Birhman and Kang, (1993) reported either negative or absence of correlation between number of tubers and tuber yield. There was a highly significant positive correlation between average tuber weight and tuber yield; and a negative correlation between average tuber weight and number of tubers suggesting that selecting for increase in average tuber weight would lead to a reduction in number of tubers.

Number of tubers per plant $\left(R^{2}=0.383\right)$ and average tuber weight per plant $\left(R^{2}=0.125\right)$ had the highest coefficients of determination of yield (Table 5) and by far the highest direct effects on tuber yield $(87.5 \%$ and $66.9 \%$ respectively) when compared to attributes (Table 6 ) suggesting that they were the major contributors to tuber yield under supra-optimal temperature conditions and may be relied upon as indices for selection for improved tuber yield under such conditions. Further more path coefficient analysis (Table 6) showed that the observed correlation between tuber yield and number of stems, plant height, number of leaves, days to tuber initiation and maturity were largely indirect through their effect on tuber number and average tuber weight. 
Table 3: Correlation coefficient $(r)$ between potato attributes at Saminaka in the year 2000

\begin{tabular}{|c|c|c|c|c|c|c|c|c|c|c|}
\hline Traits & $\begin{array}{l}\text { Number of } \\
\text { stems/pt. }\end{array}$ & Plant height & $\begin{array}{l}\text { Number of } \\
\text { leaves/pt }\end{array}$ & $\begin{array}{l}\text { Days to } \\
\text { tuber } \\
\text { initiation }\end{array}$ & $\begin{array}{l}\text { Days to } \\
\text { maturity }\end{array}$ & $\begin{array}{l}\text { Early blight } \\
\text { severity }\end{array}$ & $\begin{array}{l}\text { Number of } \\
\text { wilted plants }\end{array}$ & $\begin{array}{l}\text { Number of } \\
\text { tubers/pt }\end{array}$ & $\begin{array}{l}\text { Average } \\
\text { tuber weight }\end{array}$ & $\begin{array}{l}\text { Tuber } \\
\text { yield/pt }\end{array}$ \\
\hline $\begin{array}{l}\text { Plant } \\
\text { Emergence }\end{array}$ & 0.053 & 0.098 & $0.167^{*}$ & -0.046 & -0.031 & 0.038 & -0.146 & 0.000 & -0.072 & -0.006 \\
\hline $\begin{array}{l}\text { Number of } \\
\text { stems/pt. }\end{array}$ & & 0.043 & 0.002 & -0.136 & -0.128 & 0.148 & $0.183^{*}$ & 0.077 & 0.160 & $0.246^{\star *}$ \\
\hline $\begin{array}{l}\text { Plant } \\
\text { height }\end{array}$ & & & $0.356^{* *}$ & 0.094 & -0.081 & $-0.362^{* *}$ & 0.058 & -0.005 & $0.235^{\star *}$ & $0.206^{*}$ \\
\hline $\begin{array}{l}\text { Number of } \\
\text { leaves/pt }\end{array}$ & & & & 0.022 & 0.142 & $-0.251^{* *}$ & 0.044 & 0.105 & 0.139 & $0.237^{\star *}$ \\
\hline $\begin{array}{l}\text { Days to } \\
\text { tuber } \\
\text { initiation }\end{array}$ & & & & & $0.419^{* *}$ & $-0.370^{* *}$ & -0.100 & $-0.208^{*}$ & -0.103 & $-{ }^{-} .284^{* *}$ \\
\hline $\begin{array}{l}\text { Days to } \\
\text { maturity }\end{array}$ & & & & & & $-0.208^{*}$ & -0.078 & -0.044 & -0.147 & $-0.165^{*}$ \\
\hline $\begin{array}{l}\text { Early blight } \\
\text { severity }\end{array}$ & & & & & & & -0.022 & 0.054 & -0.175 & -0.036 \\
\hline $\begin{array}{l}\text { Number of } \\
\text { wilted } \\
\text { plants }\end{array}$ & & & & & & & & 0.029 & -0.020 & 0.067 \\
\hline $\begin{array}{l}\text { Number of } \\
\text { tubers/pt }\end{array}$ & & & & & & & & & $-0.372^{* *}$ & $0.619^{* *}$ \\
\hline $\begin{array}{l}\text { Average } \\
\text { tuber } \\
\text { weight }\end{array}$ & & & & & & & & & & $0.354^{* *}$ \\
\hline
\end{tabular}


Table 4: Simple regression coefficients between *tuber yield and yield components in Saminaka in the year 2000

\begin{tabular}{l|ll}
\hline Attributes & Regression coefficient & level of significance \\
\hline Plant Emergence & -0.21 & $\mathrm{~ns}$ \\
Number of stems/pt. & 19.44 & $\mathrm{p}<0.001$ \\
Plant height & 1.33 & $\mathrm{p}<0.05$ \\
Number of leaves/pt & 0.56 & $\mathrm{p}<0.01$ \\
Days to tuber initiation & -3.04 & $\mathrm{p}<0.001$ \\
Days to maturity & -1.77 & $\mathrm{p}<0.05$ \\
Early blight severity & -2.64 & $\mathrm{~ns}$ \\
Number of wilted plants & 3.34 & $\mathrm{~ns}$ \\
Number of tubers/pt & 20.94 & $\mathrm{p}<0.001$ \\
Average tuber weight & 1.60 & $\mathrm{p}<0.001$ \\
\hline
\end{tabular}

${ }^{*}$ Dependent variable $=$ tuber yield $/$ plant

Table 5: Coefficient of determination $\left(R^{2}\right)$, Adjusted $R^{2}$ and Standard error of the estimate for the regression of tuber yield on yield components of potato in Saminaka in the year $\mathbf{2 0 0 0}$

\begin{tabular}{l|lll}
\hline Attributes & $\begin{array}{l}\text { Coefficient of } \\
\text { determination }\end{array}$ & Adjusted $\mathbf{R}^{2}$ & $\begin{array}{l}\text { Standard error } \\
\text { of estimate }\end{array}$ \\
\hline Plant Emergence & 0.000 & -0.007 & 47.221 \\
Number of stems/pt. & 0.060 & 0.054 & 45.772 \\
Plant height & 0.042 & 0.036 & 46.209 \\
Number of leaves/pt & 0.056 & 0.050 & 45.873 \\
Days to tuber initiation & 0.081 & 0.074 & 45.280 \\
Days to maturity & 0.027 & 0.020 & 46.578 \\
Early blight severity & 0.001 & -0.006 & 47.192 \\
Number of wilted plants & 0.005 & -0.002 & 47.115 \\
Number of tubers/pt & $0.383^{* \star *}$ & 0.379 & 37.096 \\
Average tuber weight & $0.125^{* *}$ & 0.119 & 44.161 \\
\hline
\end{tabular}

Potato tuber yield is influenced largely by the number of tubers and average tuber weight (Birhman and Kang, 1993). Lynch and Kozub (1991) observed that while number of tubers was more important in determining tuber yield in some progenies and environments, it was average tuber weight that was more important for tuber yield determination in other genotypes and environments. In this study, number of tubers was more important than average tuber weight for tuber yield determination going by its higher coefficient of determination (Table 5) and direct effect (Table 6).

Multiple correlation coefficient for the relationship between tuber yield and other attributes was highly significant and positive (0.891) (Table 7). This means that $89 \%$ variation in tuber yield can be attributed to the influence of the ten attributes assessed. The multiple regression was also very highly significant (Table 7).

Results presented in this study showed that number of tubers per plant and average tuber weight per plant were the major contributors to yield under supraoptimal temperature conditions and may be relied upon as indices for selection for improved yield under such conditions.

\section{ACKNOWLEDGEMENTS}

The authors are grateful to the Executive Director National Root Crops Research Institute Umudike for the permission to publish this work and to the technical and field staff of the Potato Programme Kuru and Kaduna State Agricultural and Rural Development Project for their assistance. 
Table 6: Path analysis showing direct and indirect influences of 10 attributes on tuber yield per plant of potato genotypes in Saminaka in1999

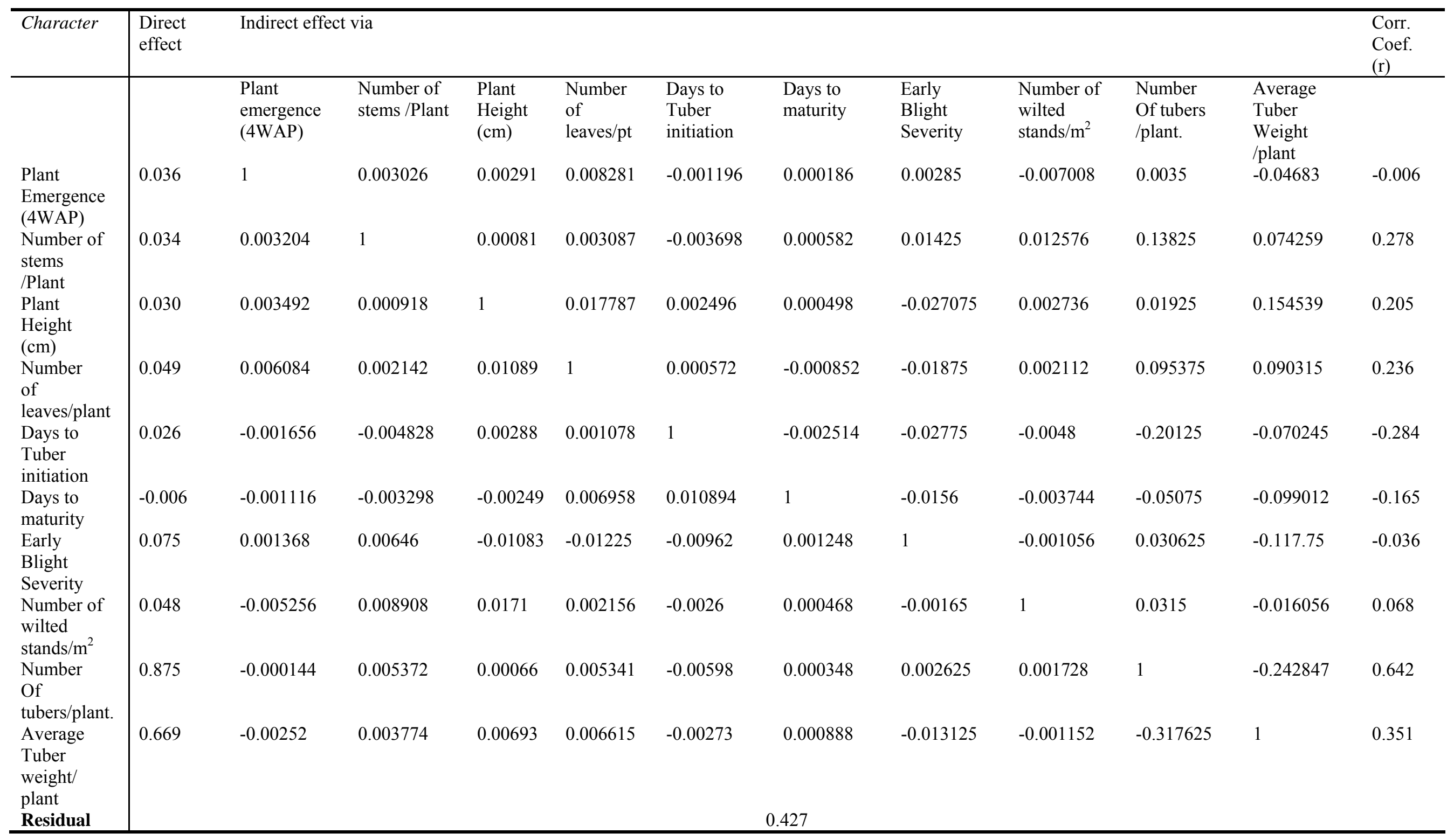


Table 7: Multiple correlation and regression of tuber yield on other potato plant attributes in Saminaka the year 2000

\begin{tabular}{c|cccc}
\hline $\begin{array}{c}\text { Source of } \\
\text { variation }\end{array}$ & $\begin{array}{c}\text { degree of } \\
\text { freedom }\end{array}$ & sum of squares & mean squares & $f$ value \\
\hline Regression & 10 & 251476.43 & 25147.643 & $51.327^{\text {** }}$ \\
Residual & 133 & 65163.461 & 489.951 & \\
Total & 143 & 316639.89 & & \\
\hline
\end{tabular}

\section{Coefficient of determination Multiple correlation Standard error of estimate}
$0.794^{* * *}$ $0.891^{* * *}$ 22.135

$Y=-130.94+1.14 X_{1}+4.33 X_{2}+0.00 X_{3}+0.11 X_{4}-0.13 X_{5}-$
$.08 X_{6}+3.60 X_{7}+2.21 X_{8}+28.61 X_{9}+2.94 X_{10}$

Where: $\mathrm{X} 1$ = Plant emergence, $\mathrm{X} 2$ = Number of stems, X3 =Plant height, $\mathrm{X} 4=$ Number of leaves, $\mathrm{X} 5=$ Days to tuber initiation, $X 6$ =Days to maturity, $X 7=$ Early blight severity, $X 8=$ Number of wilted plants $X 9=$ Number of tubers, $\mathrm{X} 10=$ Average tuber weight,

\section{REFERENCES}

Allen, E.J., O'brien, P.J. and Firman, D., 1992. Seed tuber production and management. In: The Potato Crop (edited by P.M. Harris) Chapman and Hall London pp 247-287.

Amadi, C. O., 2005. Evaluation of potato genotypes for adaptation to heat stress. PhD Thesis Michael Okpara University of Agriculture Umudike. 285pp

Birhman, R. K. and Kang, G. S., 1993. Analysis of variation and inter -relationships in potato germplasm. Euphytica 68:17-26

Borah, M.N. and Milthorpe F. L., 1962. Growth of potato as influenced by temperature. Indian J. Plant Physiology, 5:53-72

Bushnell, J., 1925. The relationship of temperature to growth and respiration in the potato plant Tech. Bull. Minn. Agric. Exp. Stn. No. 34, 29pp.

Dewey, D. R. and LU, K. H., 1959. A correlation and path coefficient analysis of components of crested wheat grass seed production. Agron. J., 51:515518.

Ewing, E.E., 1981. Heat stress and tuberization stimulus. Am. Potato J., 58:31-49.

Gomez, K.A. and Gomez, A. A., 1984. Statistical Procedure for Agricultural Research John Wiley and sons New York. $2^{\text {nd }}$ edition. 680pp

Hawkes, J. G., 1978. History of potato. In: P. M. Harris ed. The Potato Crop. The Scientific Basis for Improvement. Chapman and Hall, London, pp. 114
Levy, D., 1983. Varietal differences in the response of potato to repeated short periods of water stress in hit climates. 2. Tuber yield and dry matter accumulation and other tuber properties. Potato Res., 26: 315-321

Levy, D., 1984. Cultivated Solanum tuberosum L. as a source for the selection of cultivars adapted to hot climates Trop Agric. (Trinidad), 61:167-70

Lopez, D. F., Boe, A.A., Johansen, R.H. and Jansky, S.H., 1987. Genotype x Environment interactions, correlations and combining ability of six traits in potato (abstract) Am. Potato J. 64:447

Lynch, D.R. and Kozub, G.C., 1991. The association between potato tubers yield and components of yield in irrigated and dry land environments in the prairies. Can. J. Plant Sci 71: 279-287.

Martin, C. and Thurston, H. D., 1989. Factors affecting resistance to Alterneria solani and progress in early blight research at CIP. In: Fungal diseases of the potato report of the planning conference on fungal diseases of potato held at CIP, Lima 1987 101-118

Menzel, C. M., 1980. Tuberization in potato at high temperatures: responses to gibberillins and growth inhibitors. Annals of Botany, 46:259-265

Midmore, D. J., 1984. The potato (Solanum spp) in the hot tropics 1. Soil temperature effects on emergence, plant development and yield. Field crops Res. 8: 255 - 71

Nowak, J. and Coleborne, D., 1989. In vitro tuberization and tuber proteins as indicators of heat tolerance in potato. American Potato Journal, 66: 35 - 45

Sale, P.J.M., 1974. Productivity of vegetable crops in a region $f$ high solar input III. Carbon balance of potato crops, Austral. J. PI. Physiol. 1:283 - 96.

Sidhu, A. S. and Pandita, M. L., 1979. Genetic variability and correlation studies in potato (Solanum tuberosum L). J. Indian Potato Assoc. 6:103-108. 